\title{
Lithofacies and depositional environments of the Paleogene/Neogene sediments in the Hoanh Bo Basin (Quang Ninh province, NE Vietnam)
}

\author{
Hoang Van Tha ${ }^{1,2}$, Anna Wysocka ${ }^{2}$, Phan Dong Pha ${ }^{3}$, \\ Nguyen Quoc Cuong ${ }^{1}$, Piotr Ziółkowski \\ ${ }^{1}$ Viet Nam Academy of Sciences and Technology, Institute of Geological Sciences; \\ 84 Chua Lang Str., Dong Da, Ha Noi, Vietnam; e-mail: thahoangvan@gmail.com \\ ${ }^{2}$ University of Warsaw, Faculty of Geology; ul. Żwirki i Wigury 93, 02-089 Warsaw, Poland \\ ${ }^{3}$ Viet Nam Academy of Sciences and Technology, Institute of Marine Geology and Geophysics; \\ 18 Hoang Quoc Viet Str., Cau Giay, Ha Noi, Vietnam
}

(C) 2015 Authors. This is an open access publication, which can be used, distributed and reproduced in any medium according to the Creative Commons CC-BY 4.0 License requiring that the original work has been properly cited.

Received: 16 July 2015; accepted: 26 November 2015

\begin{abstract}
The Hoanh Bo Basin is a multiple period formed basin which is associated with the tectonic mechanism due to the activity of the Chi Linh-Hon Gai and Trung Luong Faults during the late Paleogene - early Neogene time. The basin is filled with continental sediments, comprising mainly polymictic conglomerates, sandstones, siltstones, claystones and shales. Coarser-grained polymictic deposits predominate along the northern and western margins of the basin, while different types of siltstones, claystones, even sandstones occur in its center, as well as along its southern and eastern parts toward the Ha Long Bay. The source rocks for sedimentary materials are mainly originated from rocks of the Hon Gai and Ha Coi Formations.

Based on the dominant grain-size class, texture, stratification, degree of clast rounding and sorting, 17 lithofacies were determined in the Hoanh Bo Basin infill. The basin is filled by gravelly, sandy and fine-grained lithofacies just covers a modest area but it represents a full of succession of 4 depositional systems including alluvial fan, fluvial, deltaic and lacustrine environments. Alluvial fan and fluvial environments are characterized by an assemblage of lithofacies such as sand- and mud-supported disorganized breccias (Gb), clast- to sand-supported conglomerates (Gmm), clast-supported inverse-graded conglomerates (Gig), planar-cross-bedded conglomerates (Gp), trough cross-bedded conglomerates (Gt), horizontally stratified conglomerates (Gh), planar cross-bedded sandstones (Sp), trough cross-bedded sandstones (St), ripple cross-laminated sandstones (Sr), horizontally bedded sandstones (Sh), massive sandstones (Sm), massive mudstones, siltstones (Fsm), laminated siltstones and mudstones (Fl), massive claystones (Fm) and coaly lithofacies (C); the deltaic assemblage is dominated by planar-cross-bedded conglomerates (Gp), horizontally stratified conglomerates (Gh), planar cross-bedded sandstones (Sp), horizontally bedded sandstones (Sh), low-angle cross-bedded sandstones (Sl); while the lacustrine assemblage consists of ripple cross-laminated sandstones (Sr), horizontally bedded sandstones (Sh), normally graded sandstones (Sng), massive mudstones, siltstones (Fsm), laminated siltstones and mudstones (Fl), massive claystones (Fm) and coaly lithofacies (C).
\end{abstract}

Keywords: terrestrial environments, lithofacies, Paleogene, Neogene, Vietnam

\section{INTRODUCTION}

The Hoanh Bo Basin is situated in the northwestern Ha Long city and its center is the Cuoc Be Bay
(Fig. 1). This area spreads over the territory of the Hoanh Bo district and Ha Long city, the Quang Ninh province. Topographically it belongs to a hilly and low-mountainous area with an average 
elevation between a hundred and several hundred meters, while its topographic surface inclines towards the south-southeast.

In the aspect of tectonics, the Hoanh Bo Basin is situated in the eastern part of the Red River Fault Zone, where the Day Nui Con Voi Massif is present, and it has key significance for understanding of the Paleogene-Neogene geodynamic evolution of the southeast Asia (Cuong \& Zuchiewicz 2001, Cuong 2007).

On the mainland, Tertiary basins were formed with the geometry of small, elongated, narrow grabens and half-grabens. They occur along main fault zones of northern Vietnam. It has also been clearly understood that sedimentation in Miocene basins display a range of features indicative of

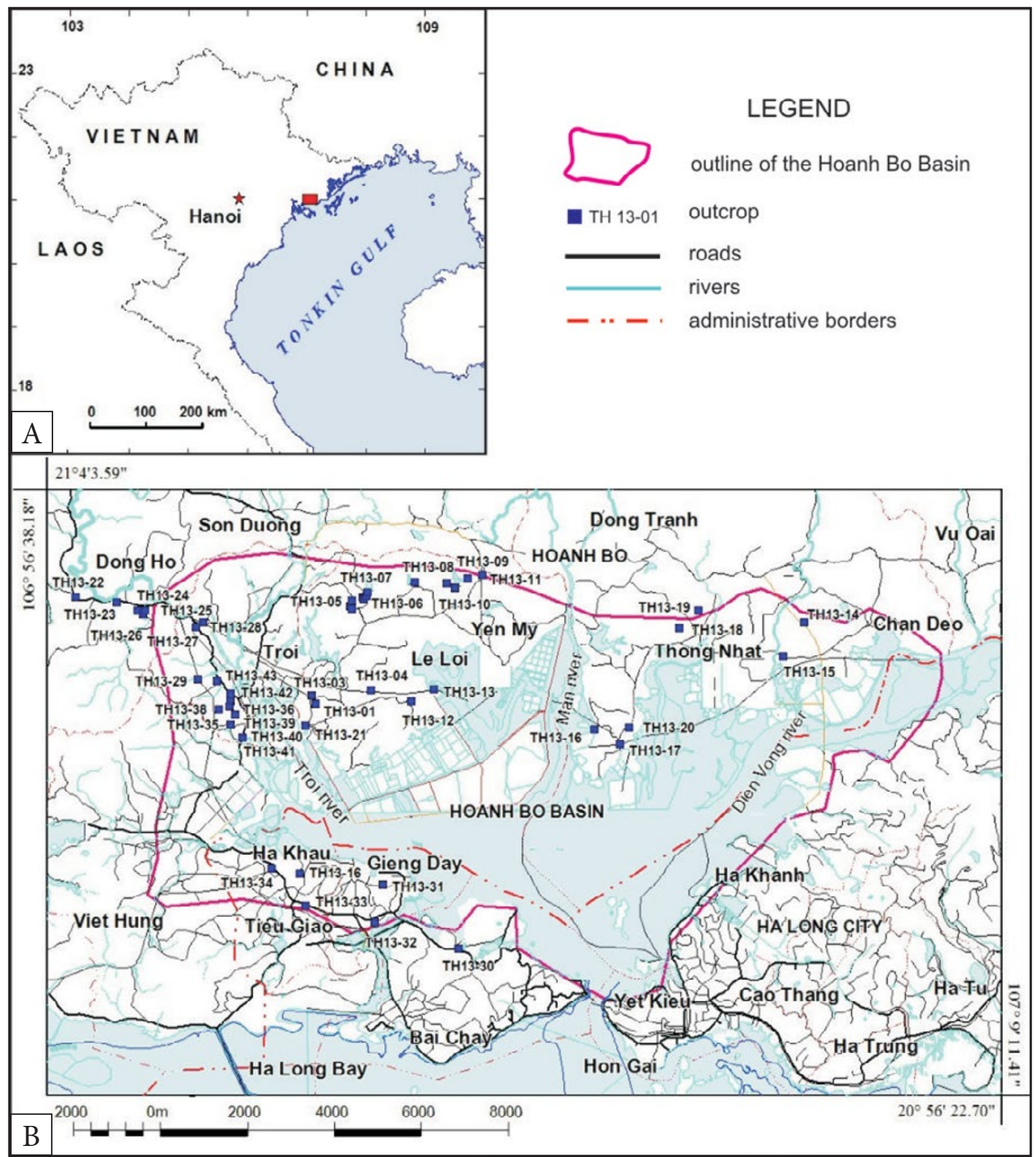

Fig. 1. Topographical sketch-map showing the location of the study area: A) location of Vietnam among adjacent countries; B) location of the Hoanh Bo basin in the Quang Ninh province (according to the topographical map sheets of The General Administration of Land of Vietnam, 2005) 
tectonically-controlled basins (Wysocka \& Świerczewska 2005, 2010).

Lying in the Quang Ninh Anticline Structure (Tri 1977), the Hoanh Bo Basin has the form of a trapezoid located between two active faults: Chi Linh - Dong Trieu and Trung Luong, with the substrate chiefly made of Triassic and Jurassic rocks (Ky 1999, Luong 1999). The Hoanh Bo Basin is filled with Oligocene, Neogene and Quaternary sediments including breccias, conglomerates, sandstones, siltstones, claystones, oil-bearing shales, with its thickness reaching over 600 m (Ky 1999, Luong 1999). Geological and stratigraphic characteristics of these continental beds have been described by some research works (Patte 1927, Dovijkov 1965, Quang et al. 1969, Nhan \& Danh 1975, Trung et al. 1999). Previous descriptions were general, without detailed sedimentological data such as descriptions of lithofacies and facies associations. Main goal of our study is to describe in details the sedimentological features and to interpret the sedimentary environments of the Hoanh Bo Basin during the Paleogene/ Neogene periods.

\section{GEOLOGICAL SETTING}

Lying in the northeastern Bac Bo Region, the Quang Ninh Zone has the form of a crescent moon overlapping the An Chau Superimposed Depression in the north-northwest. The Quang Ninh Anticlinal Structure Zone is composed of volcano-clastic, terrigenous and carbonate sediments of Late Ordovician to Late Paleozoic ages. Their total thickness equals about $3200 \mathrm{~m}$ (Fig. 2). Apart from these, there are also Mesozoic and Cenozoic coal-bearing deposits and mixed continental red beds filling up grabens and basins with the thickness ranging between several hundred and several thousand meters. Mesozoic sediments $\left(T_{2}-J_{1-2}\right)$ occur in narrow grabens.

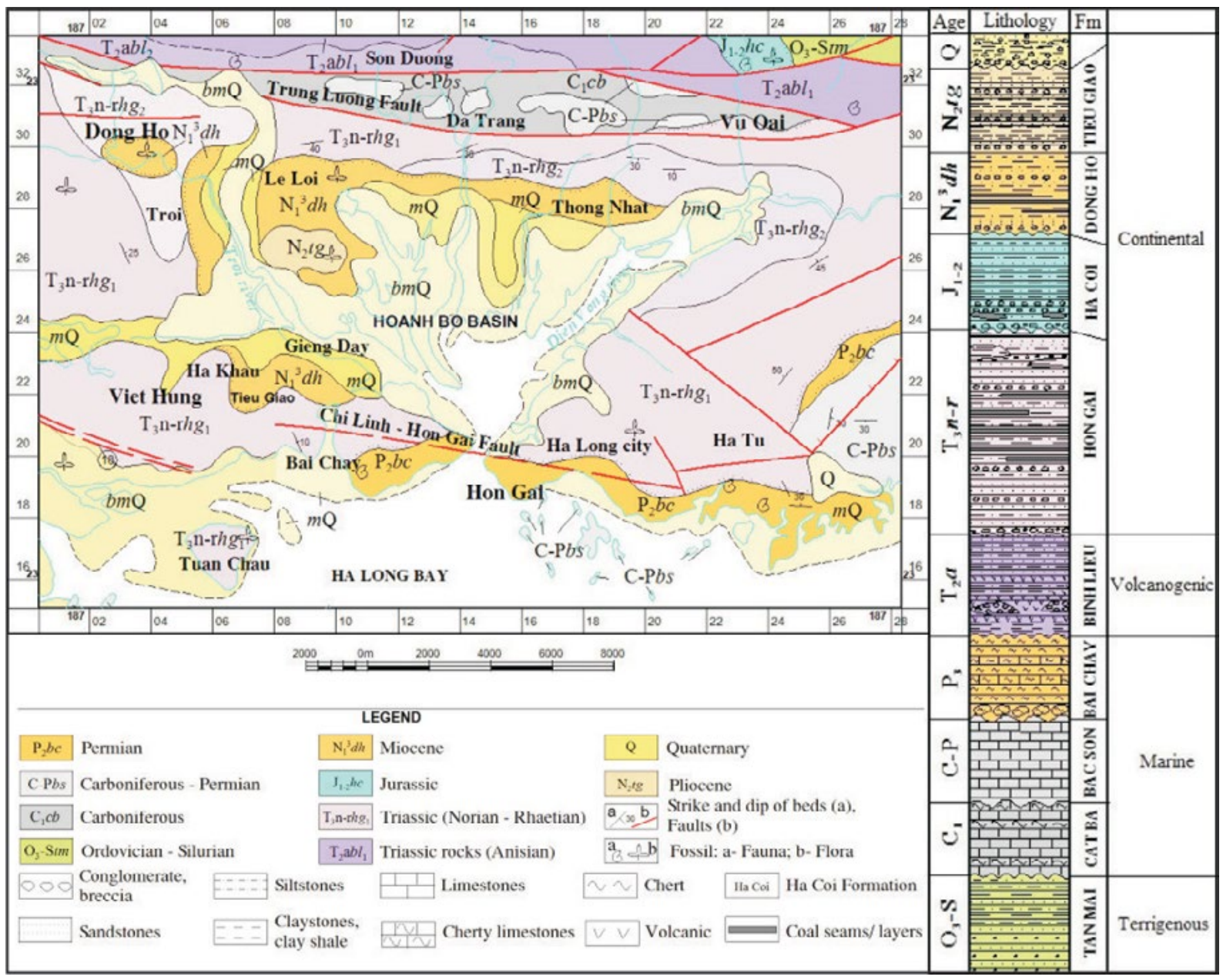

Fig. 2. Geological map of the study area (based on Luong 1999, Ky 1999) and generalized stratigraphic column for the Hoanh Bo area (based on Nhan \& Danh 1975, Liem 1985, Tuyen 1995, Luong 1999, Khuc 2001) 
The basement of the Hoanh Bo Basin is mainly built of rocks of the Hon Gai Formation $\left(\mathrm{T}_{3} n-r\right)$, including mainly quartz conglomerates, graded granule-size quartz conglomerates, thick-bedded sandstones interbedded with dark grey siltstones which contains coal seams, siltstones bearing lenses of claystones and coaly shales, thick coarse sandstones interbedded with conglomerates, granule-size conglomerates, siltstones, claystones and coal seams (Fig. 2). Moreover, in the area of Tieu Giao, Thong Nhat and in the northeastern part of the basin the investigated rocks unconformably laying on the Jurassic rocks of the Ha Coi Formation $\left(J_{1-2}\right)\left(U_{y} 1995\right)$.

Presently, the Hoanh Bo Basin is a brachysyncline with the width of $7.5-8.0 \mathrm{~km}$ and the length of $12-13 \mathrm{~km}$ widening northward. It lies between two major faults: the Chi Linh- Hon Gai Fault in the south and the Trung Luong Fault in the north. These faults play an important role in the evolution of the basin. The Trung Luong Fault has an arc-like geometry with its shear surface inclined southward. During late Mesozoic and pre-Cenozoic time this fault activated as a reverse one creating sub-vertical surfaces dipping to the northeastern direction (Viet 2003). The activity of this fault was of a normal strike-slip kind during the Cenozoic (Chinh 2002).

The Chi Linh-Hon Gai fault is a strike-slip fault which extends along more than $200 \mathrm{~km}$. The shear surface is inclined at $40^{\circ} \mathrm{N}$ (NNE) with the dip angle of approximately $80^{\circ}$ (Chinh 2002, Viet 2003). During the Pliocene-Quaternary periods, its translation was a normal strike-slip mechanism (Tuc 2004). In addition, the Hoanh Bo Basin was also disturbed by small faults with different trends such as a northeast-southwest, almost perpendicular with a northwest-southeast longitude trend.

The Hoanh Bo Basin is filled with deposits of the Dong Ho Formation $\left(\mathrm{N}_{1}^{3} d h\right)$ and Tieu Giao Formation $\left(\mathrm{N}_{2} \operatorname{tg}\right)$ (Fig. 2). According to the primary description by Nhan \& Danh (1975), the typical section was exposed along the Dong Ho stream and the Troi - Bang Be road. The lithostratigraphic column of the Dong Ho Formation is composed of 7 members. They include thick-bedded grey conglomerates, sandstones, siltstones, oil-bearing shales, thin coal seams and thick-bedded claystones. The siltstones, claystones and oil-bearing shales usually contain an assemblage of spores and pollens of Gleichenia sp., Quercus sp., Liquidambar sp., and leaf imprints of Pecopteris totangensis, Magnolia janschinii, Laurus nobilis. The total thickness of this formation reaches 140-418 m. Currently, the age of the Dong Ho Formation has been confirmed as Oligocene (Trung 1999).

The Tieu Giao Formation $\left(\mathrm{N}_{2} t g\right)$ consists of coarse-grained continental deposits extending limitedly in some small outcrops, such as the Tieu Giao, Xich Tho, Troi. This formation includes weakly cemented conglomerates, gritstones and sandstones, and some thin interbeds or lenses of ashy grey argillaceous shales. The conglomerate pebbles are mainly composed of badly rounded and angular quartzite and sandstone grains. Plant remains were collected from the argillaceous shales, with predominance of Fagus sp. and Phoebe sp. (Fagus cf. stuxbergii - Phoebe pseudolanceolata assemblage). The thickness of this formation varies from $120 \mathrm{~m}$ to $200 \mathrm{~m}$. According to Trinh Danh (1975), the collected flora fossils belong to the Phragmites oeningensis - Quercus neriifolia assemblage of Pliocene age. Currently, the Tieu Giao Formation is determined to be of Miocene age (Thanh \& Khuc 2009).

\section{MATERIALS AND METHODS}

The studied deposits were sampled in small outcrops, as well as along the scarps of the roads. Some outcrops were explored earlier in 1999, 2000 and 2004, but most observations, measurements and sample collecting were performed in 2013. Investigations were conducted in a total of 43 outcrops (Fig. 1B). During research on lithofacies, a number of important sedimentary features have been tested including: grain-size analysis, texture, structure, as well as the degree of clast rounding and sorting. In the case of conglomerates, the sedimentological features were measured directly in the field. The hand-specimens were mainly checked directly in the field by the hand lens and in some cases, thin-sections were described under the reflected light microscope.

The grain-size scale and the sedimentary rocks were identified according to the classifications of Udden (1914), Wentworth (1922) and Pettijohn et al. (1972), respectively; the roundness of the grains followed the categories of Pettijohn et al. (1987); the lithofacies were described following Miall's concept (Miall 1977, 1978, 2006). 


\section{LITHOFACIES}

17 lithofacies have been identified based on field and laboratory data. Mixed deposits were ascribed to relevant lithofacies based on the predominant grain constituent.

\section{Gravely lithofacies}

The gravely lithofacies were observed mainly at the lower part of the sedimentary section, especially in the area surrounding the center of the basin. Six lithofacies were identified, including sand- and mud-supported disorganized breccias (Gb), clast- to sand-supported conglomerates $(\mathrm{Gmm})$, clast-supported inverse-graded conglomerates (Gig), planar-cross-bedded conglomerates $(\mathrm{Gp})$, trough cross-bedded conglomerates (Gt), horizontally stratified conglomerates (Gh) (Tab. 1, Fig. 3).

Table 1

Gravely lithofacies characteristic; lithofacies code based on Miall (2006)

\begin{tabular}{|c|c|}
\hline Lithofacies & Description and interpretation \\
\hline $\begin{array}{l}\text { Sand- and mud-supported } \\
\text { disorganized breccias (Gb) }\end{array}$ & $\begin{array}{l}\text { - widely ranging grain size (pebble to cobble, occasionally block size) } \\
\text { - amalgamated structure } \\
\text { - angular to sub-rounded clasts } \\
\text { - poorly sorted } \\
\text { - sand-matrix supported } \\
\text { - thickness reaching several meters, over } 10 \mathrm{~m} \text { in length } \\
\text { Rock avalanche and/or debris flow }\end{array}$ \\
\hline $\begin{array}{l}\text { Clast- to sand-supported } \\
\text { conglomerates }(\mathrm{Gmm})\end{array}$ & $\begin{array}{l}\text { - widely ranging grain size (pebble to cobble) } \\
\text { - highly amalgamated } \\
\text { - sub-rounded to well-rounded clasts } \\
\text { - clast-supported } \\
\text { - structural bodies with sharp bounding } \\
\text { - convex-up geometry } \\
\text { - thickness reaching up to several meters } \\
\text { Deposition from debris flows or pseudoplastic debris flows, active bedload transport }\end{array}$ \\
\hline $\begin{array}{l}\text { Clast-supported inverse- } \\
\text { graded conglomerates (Gig) }\end{array}$ & $\begin{array}{l}\text { - pebble-size clasts, occasionally cobble size-clasts } \\
\text { - heterogeneous and poorly defined } \\
\text { - sub-rounded to well-rounded clasts } \\
\text { - clast- to sand-supported conglomerates, coarse-sand matrix } \\
\text { - upward coarsening grain size } \\
\text { - up to } 2.4 \mathrm{~m} \text { thick } \\
\text { High-energy debris flow or a low energy flow with an inertial bed load transported } \\
\text { by laminar to turbulent flow or sweeping of gravel sheets across the bar tops, or } \\
\text { development of a fan lobe }\end{array}$ \\
\hline $\begin{array}{l}\text { Trough cross-bedded } \\
\text { conglomerates (Gt) }\end{array}$ & $\begin{array}{l}\text { - pebble- to cobble-sized clasts and granule-sized clasts } \\
\text { - shallow scoop-shaped cross-sets } \\
\text { - sub- to well-rounded clasts } \\
\text { - matrix-supported conglomerates } \\
\text { - bed thickness is } 5-15 \text { meters, } 50 \mathrm{~m} \text { to over } 100 \mathrm{~m} \text { in length } \\
\text { Infill of minor channels caused by channel system avulsion and leaving of an abandoned } \\
\text { channel or migration of transverse bedforms with curved crests }\end{array}$ \\
\hline $\begin{array}{l}\text { Planar-cross-bedded } \\
\text { conglomerates }(\mathrm{Gp})\end{array}$ & $\begin{array}{l}\text { - granule- to pebble-sized clasts } \\
\text { - wedge-shaped cross-sets and planar cross-beds with cross-stratified angle up to } 30^{\circ} \\
\text { - sub-rounded- to well-rounded clasts } \\
\text { - sand matrix-supported conglomerates } \\
\text { - thickness between several decimeters and several meters, several m in length } \\
\text { Deposition from bedload transport, migration of bar form }\end{array}$ \\
\hline $\begin{array}{l}\text { Horizontally stratified } \\
\text { conglomerates (Gh) }\end{array}$ & $\begin{array}{l}\text { - granule- to pebble-sized clasts, occasionally cobbles } \\
\text { - crude horizontal stratification and rapid upward fining } \\
\text { - sub- to well-rounded clasts } \\
\text { - clast-supported or matrix-supported } \\
\text { - thickness between } 1 \mathrm{~m} \text { and over } 1 \text { meter, several } \mathrm{m} \text { in length } \\
\text { Deposition from hyper-concentrated grain flows }\end{array}$ \\
\hline
\end{tabular}



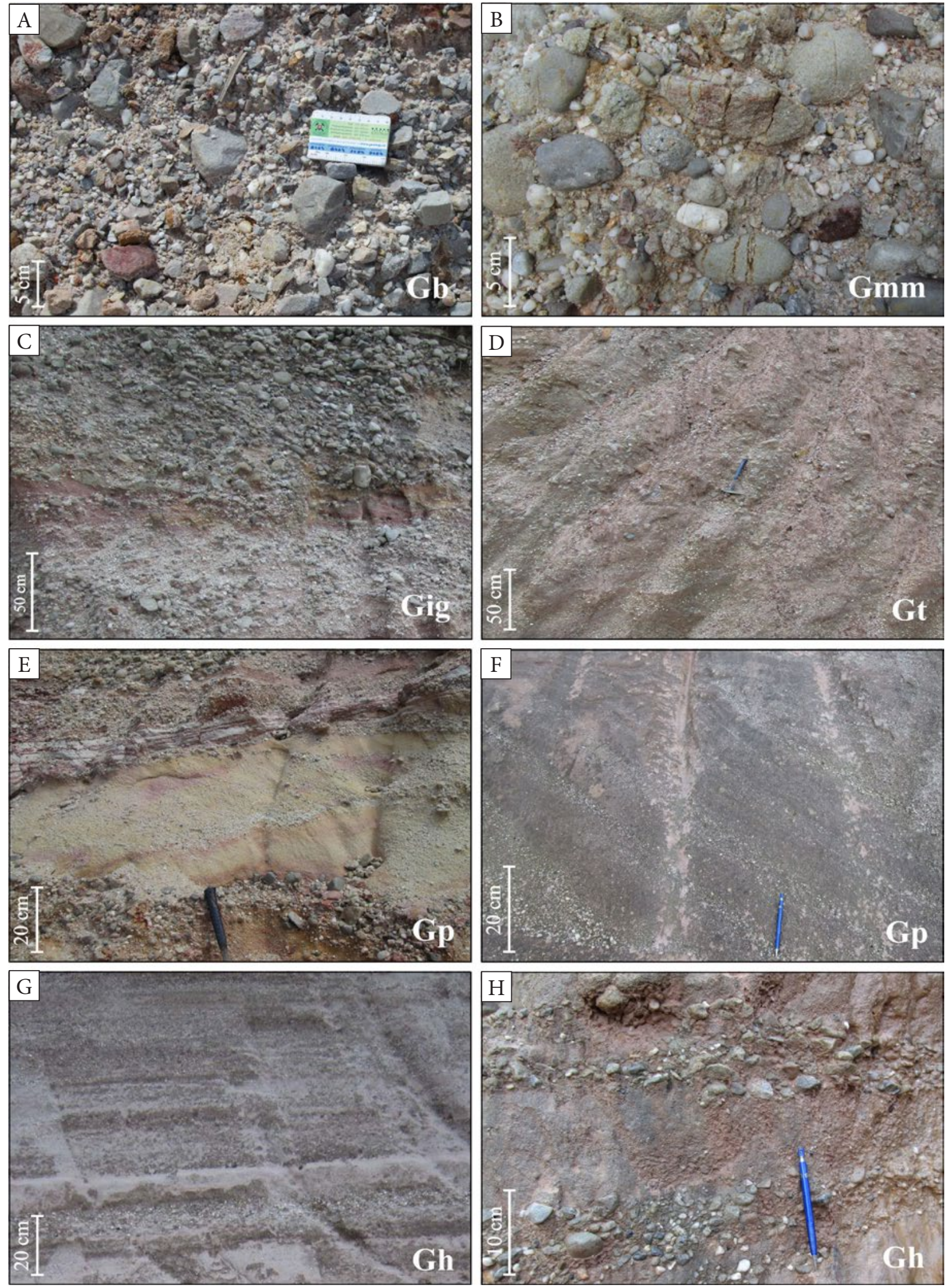

Fig. 3. Gravely lithofacies: A) sand- and mud-supported disorganized, polymictic breccias (Gb); B) massive or amalgamated, clast-supported, polymictic conglomerate (Gmm); C) heterogeneous and poorly defined, clast-supported and matrix-supported conglomerates (Gig); D) trough cross-bedded, matrix supported, polymictic conglomerate (Gt); E) and F) planar cross-bedded, matrix supported, polymictic conglomerate (Gp); G) and H) horizontally bedded, matrix supported, polymictic conglomerate (Gh) 
1) The Gb lithofacies were described for a body of sand- to mud-supported breccias. They were identified in the northwest of the basin belonging to Troi (Fig. 3A). In vertical section of this exposure displays a crude stratification without erosion-surface among beds but the boundary line between them is sharp. They were superimposed each other. In Le Loi and Thong Nhat, the beds of Gb lie unconformably upon the Triassic rocks. One typical feature of these bodies is the crude orientation of clasts along the hill slope, but with commonly amalgamated structure. This type of sediment was formed by a rock avalanche and/or debris flow (Blair \& McPherson 1994, Wysocka \& Świerczewska 2010).

2) The Gmm lithofacies identified in the west of the basin belong to the Troi section with thickness reaching up to several meters (Fig. 3B). The lithofacies were first recognized by Rust (1978b) with the code Gms (for matrix supported gravel), later in the year 2006 Miall separated them into Gmm and Gmg to distinguish massive and graded units. The beds $\mathrm{Gmm}$ are the bodies of polymictic clast-supported conglomerates and matrix-supported conglomerates. They are of massive structure. The bounding surfaces are rather sharp but there is a non-erosional contact with underlying bed. They commonly have abrupt lateral terminations. In the internal structure of beds represent the preferred orientation fabric of clasts and imbrication indicating unidirectional flow. They were deposited by debris flows or pseudoplastic debris flows, in active bedload transport (Miall 2006, Wysocka \& Świerczewska 2010).

3) The Gig lithofacies identified in the west of the basin belong to the Troi section (Fig. 3C). The beds are heterogeneous and poorly defined, clast-supported and matrix-supported conglomerates. They could be deposited by a high energy debris flow or in a low energy flow with an inertial bedload transport by laminar to turbulent flow (Miall 2006). However, this case can be interpreted that they also were deposited by the sweeping migration of gravel sheets across the bar tops or by development of a fan lobes (Massari 1983).
4) The Gt lithofacies are distributed in the northwest part of the basin, in the Troi section as well as in the north and northeast in the Le Loi and Thong Nhat sections (Fig. 3D). They are developed as bodies of matrix-supported conglomerates. Internally, they are trough cross-bedded, shallow scoop-shaped cross-sets, these units cut into each other both laterally and vertically. The Gt bed lies on an erosive surface in the Le Loi section and a remarkably deeply cut bank was observed in the Troi section. Therefore, this case should be interpreted as infill of minor channels caused by channel system avulsion and leaving of an abandoned channel. Some examples of Gt lithofacies also represent migration of transverse bed forms with curved crests, while others represent filling of minor channels (Miall 2006).

5) The Gp lithofacies are bodies of clast-supported or sand matrix-supported conglomerates (Figs 3E, F, 7A, B). They occur in the Troi and the Le Loi sections with thickness between several decimeters and several meters, several $\mathrm{m}$ in length. The Gp beds commonly appear with a mixture of gravel and sand. They are alternated with massive sandstones, planar cross-bedded sandstones, clast- to sand-supported conglomerates $(\mathrm{Gmm})$ and especially clast-supported, horizontally stratified conglomerates (Gh). In the exposures represent a consecutive relationship with gravel mass and planar cross-bed sandstone (Sp). In turn, they rest on an erosion-surface, which developed on sandy bed. They were deposited from bedload transport, migration of transverse bar forms or deltaic growths (Miall 2006).

6) The Gh lithofacies are clast-supported, horizontally stratified and matrix-supported, horizontally stratified conglomerates (Fig. 3G, H). They have a clastic framework and an abundant sandy matrix. Their internal structure shows crude horizontal stratification and rapid upward fining trend. The preferred orientation fabric of clasts is very common. The lag deposit was observed with $20 \mathrm{~cm}$ thickness in the Troi section. In the Le Loi section represents several depositional phases of $\mathrm{Gh}$ conglomerates interbeding with sandstones (Sh). Parting lineation appears within internal structure of beds. They were deposited from hyper-concentrated grain flows (Miall 2006). 
Sedimentary profiles display that coarse-grained lithofacies are the main components of the basin infill. They are distributed along the basin edge zone with their direction towards the basin center and they are building the lower part of each sedimentary profile (Fig. 9). In the eastward area, geological information is limited because this is the downstream part of the present-day rivers where they converge and continuously flow into the Vietnam east sea. This part is also repeatedly covering by sea water during tidal activity, therefore the modern estuary and tidal sediments are still being deposited.

\section{Sandy lithofacies}

Sandy lithofacies are classified on the basis of the predominant primary sedimentary structure; detailed measurements of grain size are not required (Miall, 2006). Lithofacies were identified as massive sandstones (Sm), planar cross-bedded sandstones (Sp), trough cross-bedded sandstones (St), ripple cross-laminated sandstones (Sr), horizontally bedded sandstones (Sh), normally graded sandstones (Sng), and low-angle cross-bedded sandstones (Sl) (Tab. 2, Fig. 4).

\section{Table 2}

Sandy lithofacies characteristic; lithofacies code based on Miall (2006)

\begin{tabular}{|c|c|}
\hline Lithofacies & Description and interpretation \\
\hline Massive sandstones (Sm) & $\begin{array}{l}\text { - coarse to medium grain size } \\
\text { - poorly sorted sandstone } \\
\text { - common insets in gravely bodies } \\
\text { Deposition from bedload or the basal fill of channels }\end{array}$ \\
\hline $\begin{array}{l}\text { Planar cross-bedded } \\
\text { sandstones }(\mathrm{Sp})\end{array}$ & $\begin{array}{l}\text { - pebbly sandstone with coarse-grained sand } \\
\text { - poorly sorted } \\
\text { - } 20 \mathrm{~cm} \text { thick, } 2.5 \mathrm{~m} \text { in length } \\
\text { - they alternate with conglomerates } \\
\text { Downstream migration of bar forms, ripples and dunes }\end{array}$ \\
\hline $\begin{array}{l}\text { Trough cross-bedded } \\
\text { sandstones (St) }\end{array}$ & $\begin{array}{l}\text { - medium-grained sandstone } \\
\text { - the bottoms of these beds are lined with gravel } \\
\text { - poorly sorted } \\
\text { Deposition from migration of ripples and three-dimensional dunes or an event of scour } \\
\text { infill in deep stream channel }\end{array}$ \\
\hline $\begin{array}{l}\text { Ripple cross-laminated } \\
\text { sandstones }(\mathrm{Sr})\end{array}$ & $\begin{array}{l}\text { - fine sandstone } \\
\text { - moderately- to well-sorted } \\
\text { - this variety consists of a climbing ripple set of fine grained sandstone, type A, showing } \\
\text { cross-lamination } \\
\text { Deposition mainly from suspension, reflecting tractional deposition in ripple-phase bed } \\
\text { flow conditions }\end{array}$ \\
\hline $\begin{array}{l}\text { Horizontally bedded } \\
\text { sandstones (Sh) }\end{array}$ & $\begin{array}{l}\text { - coarse-grained sandstone or pebbly sandstone with horizontal bed, poorly sorted } \\
\text { - fine sandstone, moderately- to well-sorted, bearing layers of coalified flora pieces and fine- } \\
\text { to medium-sized, horizontally bedded, moderately sorted } \\
\text { - high percentage of monomineral quartz } \\
\text { Deposition from the upper plane-bed flows at the bar tops during low water stages or } \\
\text { predominantly suspension under plane bed flow conditions or density grain flow with } \\
\text { upper plane bed condition }\end{array}$ \\
\hline $\begin{array}{l}\text { Normally graded } \\
\text { sandstones (Sng) }\end{array}$ & $\begin{array}{l}\text { - fine- to coarse-grained sandstone } \\
\text { - thick and horizontal bedding, normal grading } \\
\text { - } 1.7 \mathrm{~m} \text { thick, up to } 58.2 \mathrm{~m} \text { in length } \\
\text { Deposition from upper plane bed flow }\end{array}$ \\
\hline $\begin{array}{l}\text { Low-angle cross-bedded } \\
\text { sandstones }(\mathrm{Sl})\end{array}$ & $\begin{array}{l}\text { - fine-grained sandstones } \\
\text { - moderately- to well-sorted } \\
\text { - thick bedding } \\
\text { - dipping about } 10-15^{\circ} \\
\text { - high percentage of monomineral quartz } \\
\text { Migration of straight-crested bars or progradation of a gentle delta slope }\end{array}$ \\
\hline
\end{tabular}



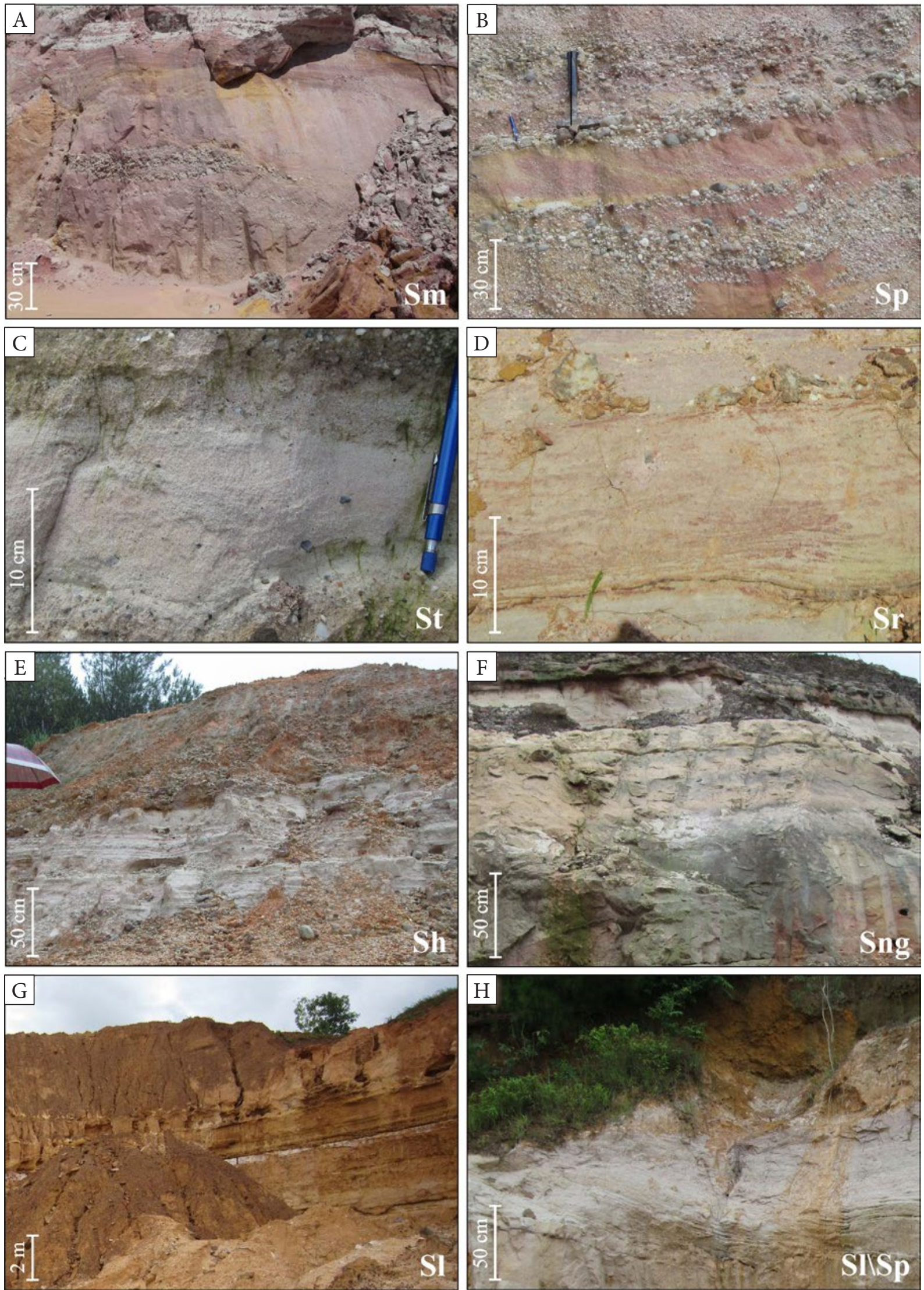

Fig. 4. Sandy litofacies: A) massive sandstones (Sm); B) planar cross-bedded sandstones (Sp); C) trough cross-bedded sandstones $(S t)$; D) ripple cross-laminated sandstones (Sr); E) horizontally bedded sandstones (Sh); F) normally graded sandstones (Sng); $\mathrm{G})$ and $\mathrm{H}$ ) low-angle cross-bedded sandstones (Sl) 

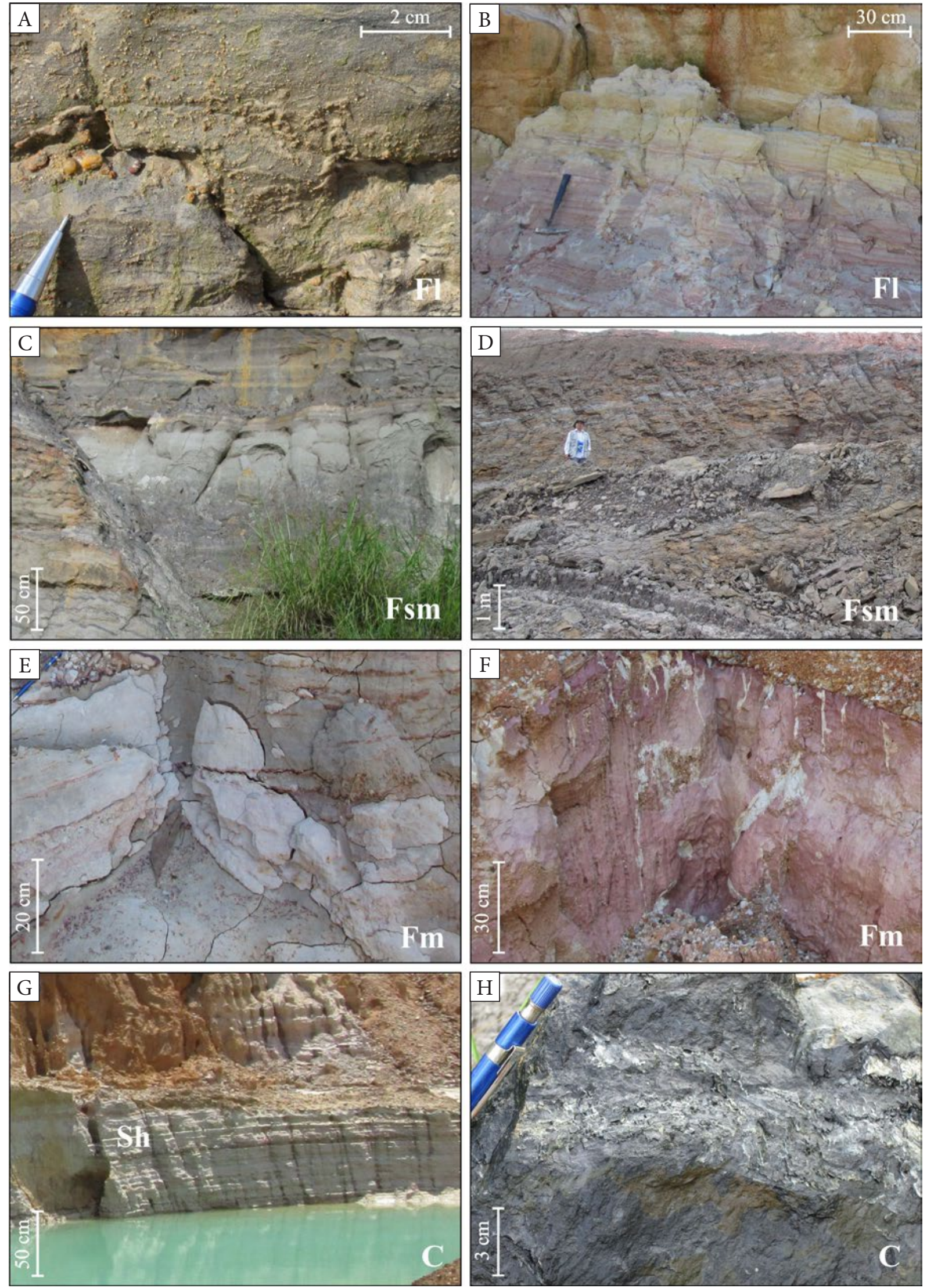

Fig. 5. Fine-grained and non-clastic lithofacies: A) and B) laminated sandstone, siltstone and mudstone (Fl); C) and D) massive siltstone and mudstone (Fsm); E) and F) massive claystone (Fm); G) and H) coaly lithofacies (C) 
Sandy lithofacies occur less commonly than gravely lithofacies. The Sm, Sp, St lithofacies are usually of lens-like geometry, present as insets in massive conglomerates $(\mathrm{Gmm})$ and with small clast dimensions in the Troi, Le Loi, Viet Hung, Ha Khau, Gieng Day sections and near the basin center (Fig. 4A, B, E). However, the Sr, Sh, Sl, Sng lithofacies are usually sheets or blanket forms distributed in the section of Le Loi, Viet Hung and near the basin center (Fig. 4C, D, F, G). Identification of the sedimentary environment is often difficult for sandy lithofacies. It could be based on paragenesis with gravel or fine-grained lithofacies to group them into different associations.

\section{Fine-grained and non-clastic lithofacies}

This group includes laminated siltstones and mudstones (Fl) (Fig. 5A, B), massive siltstones and mudstones (Fsm) (Fig. 5C, D), massive claystones (Fm) (Fig. 5E, F) and coaly lithofacies (C) (Fig. 5G, H) (Tab. 3). In general, they are also widely distributed in the study area. Typically, they are thick bedded with sheet- or blanket-like geometry. Sediments are fine- to very fine-grained, with the predominant gray to dark gray color. They are rich in orga- nic matter, leaf inprints and siderite concretions. Moreover, they are characterized by the presence of "skolithos-type" dwelling trace fossils and flaser or wavy bedding.

\section{DEPOSITIONAL ENVIRONMENTS}

\section{Alluvial fan and fluvial environments}

The typical sedimentary characteristics of this group are commonly very coarse- to coarsegrained composition, convex-up geometry, ripples (Fig. 4C, D) and imbrication (Fig. 6A). The sedimentary log shows the full profile of a fluvial environment (Fig. 9I). The lower part is mainly composed of trough cross-bedded, matrix supported, polymictic conglomerates (Gt) and massive sandstones ( $\mathrm{Sm}$ ), changing into $\mathrm{Fl}, \mathrm{Fsm}$ in the upper part, ending as an amalgamated cover bed interpreted as a colluvium (Gb). Currently, it is not easy to definitely separate the formation of alluvial fan and fluvial environments. They are combined together as the group of alluvial sediments.

The Gb, Gmm lithofacies exhibit the mechanism of avalanching or debris-flow of sedimentary materials.

Table 3

Fine, mixed and phytogenic lithofacies characteristic; lithofacies code based on Miall (2006)

\begin{tabular}{|c|c|}
\hline Lithofacies & Description and interpretation \\
\hline $\begin{array}{l}\text { Laminated sandstone, } \\
\text { siltstone and mudstone (Fl) }\end{array}$ & $\begin{array}{l}\text { - interlamination of very fine sandstones, siltstones and sandy siltstones } \\
\text { - pink to light gray color } \\
\text { - commonly flaser and wavy laminated } \\
\text { - upwardly coarsening successions } \\
\text { - thickness ranging from } 2 \mathrm{~m} \text { to } 3.0 \mathrm{~m} \text {, several meters in length } \\
\text { Deposition from suspension on the floodplain and in the lake }\end{array}$ \\
\hline $\begin{array}{l}\text { Massive siltstones and } \\
\text { mudstones (Fsm) }\end{array}$ & $\begin{array}{l}\text { - sheet of shales, siltstones and mudstones } \\
\text { - inverse graded } \\
\text { - black grey to light gray color } \\
\text { - rich in organic matter and plant remnants } \\
\text { - occasionally horizontal interlamination of siltstone and mudstone layers } \\
\text { - observed thickness ranging from } 1.0 \mathrm{~m} \text { to } 2.5 \mathrm{~m} \\
\text { Deposition from low suspension falling out in bodies of standing water, organic materials } \\
\text { were mainly in situ }\end{array}$ \\
\hline Massive claystones $(\mathrm{Fm})$ & $\begin{array}{l}\text { - very fine siltstone and claystones, occasionally as lenses in conglomerate bodies } \\
\text { - mud and clay drapes commonly occur in gravely and sandy sediments } \\
\text { Draped deposits or an abandoned channel }\end{array}$ \\
\hline Coaly lithofacies (C) & $\begin{array}{l}\text { - small lenses or thin coal layers interbedded with siltstones and claystones, even sandstone } \\
\text { - abundant, coalified organic matter } \\
\text { Deposition in overbank and/or swamp environments, in stagnant ponds }\end{array}$ \\
\hline
\end{tabular}



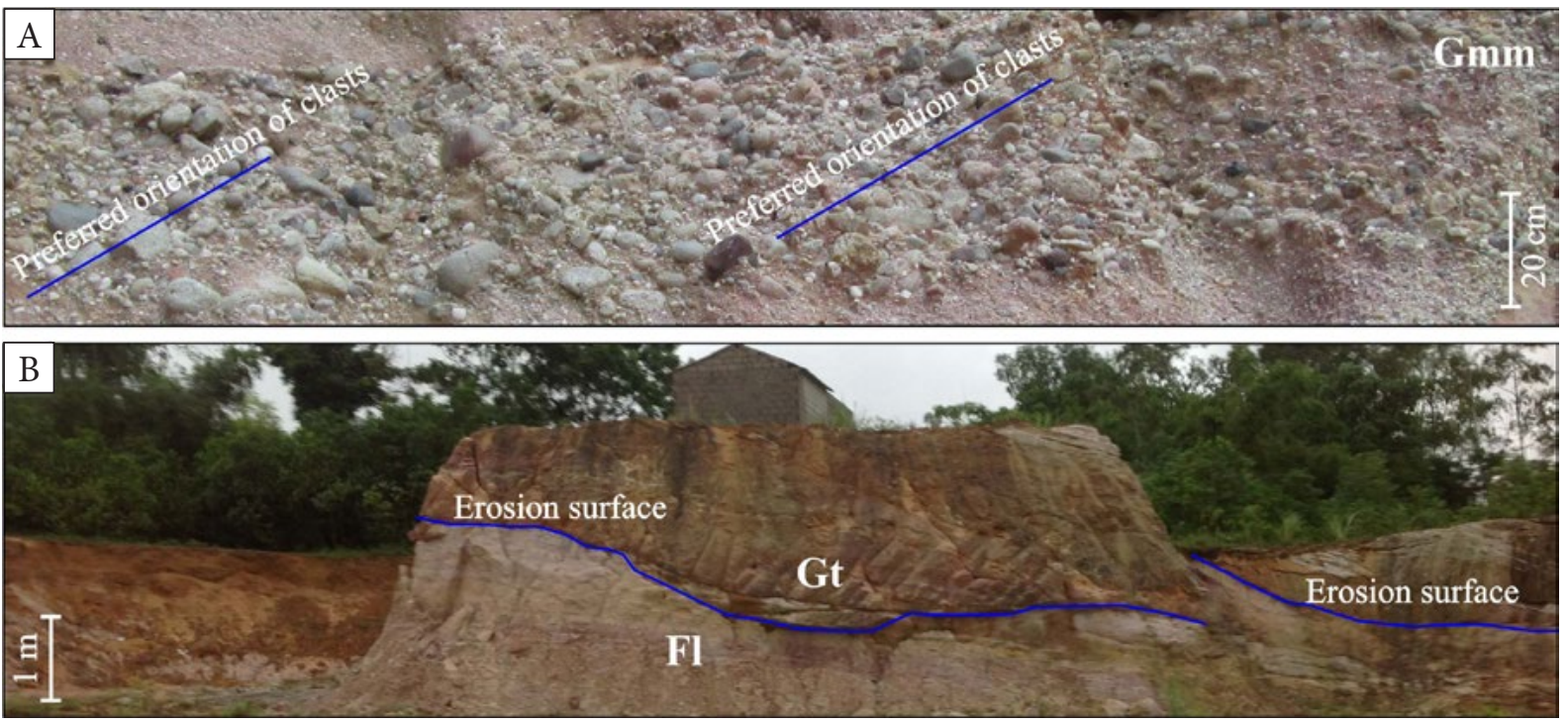

Fig. 6. Evidences for an unidirectional flow: A) imbrication within clast-supported conglomerates (Gmm); B) erosional surface in the bottom of a channel (Gt and Fl)
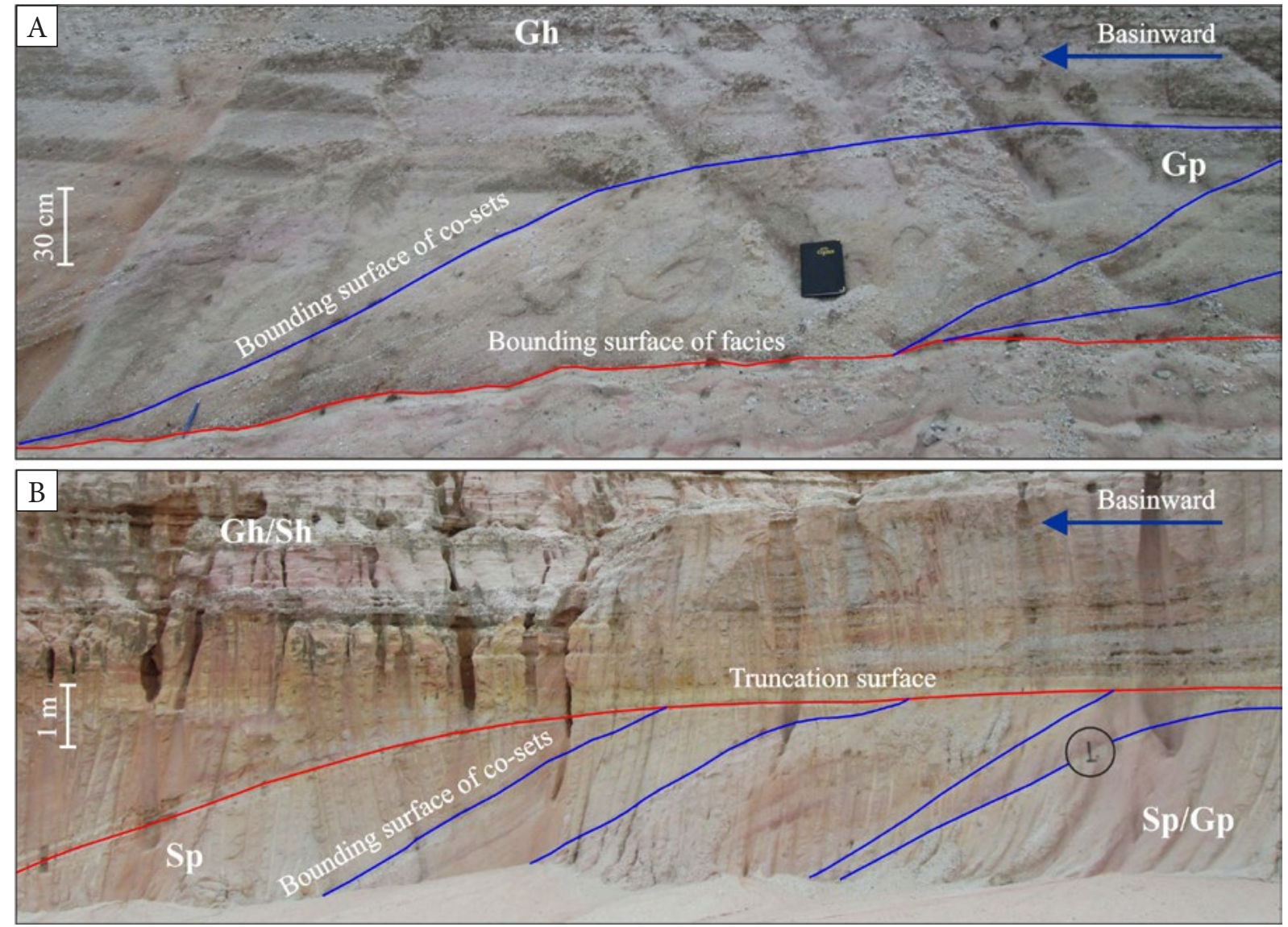

Fig. 7. Evidences for the deltaic growth: A) moderately sorted sandy conglomerate, granule-sized clasts, sandy matrix, internally showing steeply dipping beds, about $4 \mathrm{~m}$ thick and a lowstand wedge shape, associated with a crudely horizontally bedded conglomerate body (Gp) and Sp; B) granule-sized, occasionally pebble-sized clasts, sandy matrix, poorly sorted conglomerates, internally showing steeply dipping beds, $0.8 \mathrm{~m}$ thick and a lowstand wedge shape, associated part with a crudely horizontally bedded conglomerate body 
The relatively short sediment transport distance and rapid loss of flow capacity created typical features for $\mathrm{Gb}$ and $\mathrm{Gmm}$, with coarse grain size, poor sorting and variable matrix contents, polymodal grain size distribution. The thin streaks of mud commonly occur within a given body of breccias; even mud is mixed with gravelly sediments. Such patterns were associated with an alluvial fan setting (Blair \& McPherson 1994). One could observe the excellent example of an alluvial fan in the Le Loi section belonging to the northern margin of the basin.

There are many direct evidences which indicate the existence of the fluvial environment such as well-rounded clasts (in $\mathrm{Gmm}$ ), preferred orientation and imbrication (in Gmm, Gh), normal graded succession of Gmg, Gmg and Sng, planar-crossed bedding (Gp, Sp) or lag deposits. An association of the Gt, Gp, Gh, St, Sm lithofacies commonly encountered in the elements of channel facies (Miall 1978, 2006, Eberth \& Miall 1991). They were observed both in the Troi and Thong Nhat sections.
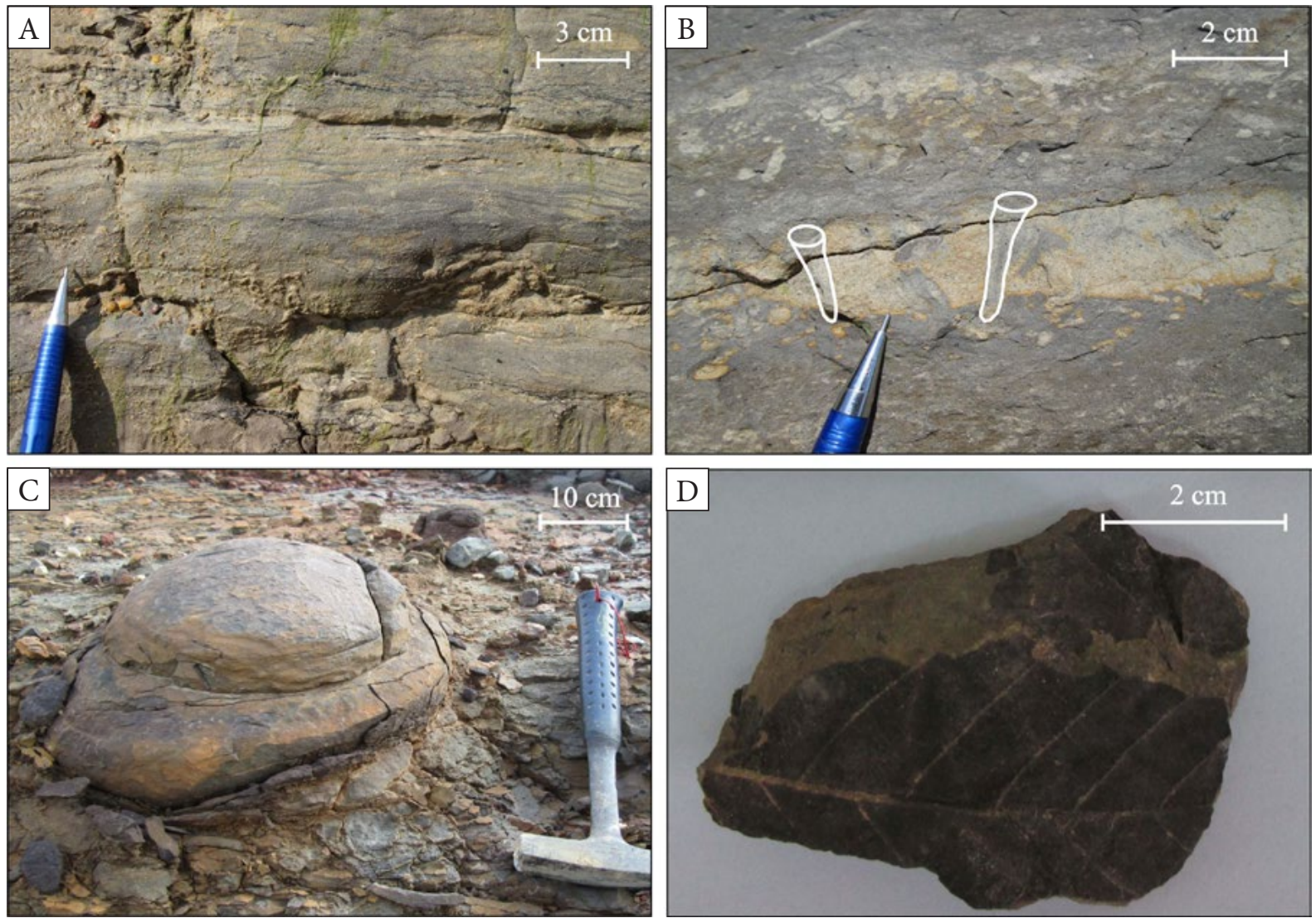

Fig. 8. Features typical for a lacustrine environment: A) flaser bedding (Fl); B) dwelling traces; C) siderite concrection; D) coalified leaf inprint

Geology, Geophysics and Environment, 2015, 41 (4): 353-369 


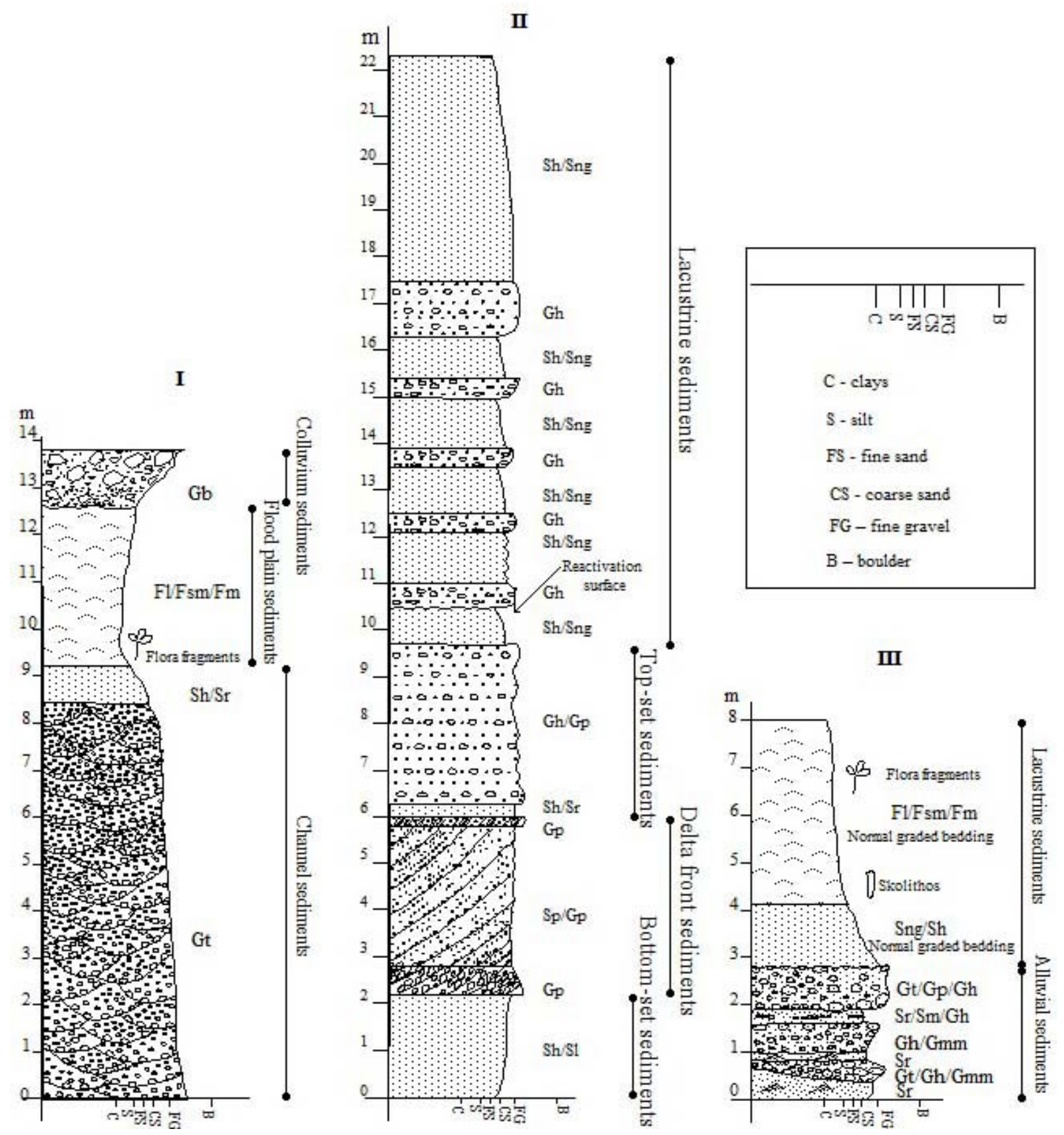

Fig. 9. Sedimentary logs: I - alluvial (the Troi section); II - deltaic (the Le Loi section); III - alluvial and lacustrine (the Le Loi section)

\section{Deltaic environment}

The deposits are generally coarse-grained, poorly sorted, polymictic and matrix-rich. The most typical structure is the steeply dipping bed including co-sets of planar cross-bedded sandy conglomerates Gp and planar cross-bedded sandstones Sp (Figs 7, 9II). The presence of a trucation surface implies that dynamics of river flow was stronger and stronger. The pre-existed Gp/Sp cosets were eroded. The beds of Gh/Sh lie upon them. The sedimentary log clearly shows the lower part of Sh, Sl and Sr (smallscale ripple), the middle part of $\mathrm{Gp}, \mathrm{Sp}$ and the upper part of Gm, Gh, Sh (Fig. 9II). On the surface of the sheet fine sandstone with small-scale-ripples (Sr) erosion traces could be observed, and it rests on conglomerates (Gh). This was interpreted as a reactivation surface, resulting from fluctuations in the river stage (Tucker 2001). The Gp/Gt might show position of the river channel flowing into the basin in the Le Loi section. Such sedimentary features 
were interpreted as the setting of coarse-grained deltas (McPherson et al. 1987, Nemec \& Steel 1988, Postma 1990). The sedimentary profile shows the lack of marine fossils and very close position with respect to lacustrine sediments.

\section{Lacustrine environment}

In the Le Loi section, it was identified as lithofacies of massive mudstones, siltstones (Fsm), laminated siltstones and mudstones (Fl), massive claystones (Fm) and coaly (C) lithofacies. They are characterized by fine-grained strata with the predominant gray to grayish black color and rhythmic lamination. Such features indicate high rate of phytogenic accumulation associated with high water table and low clastic sediment input (Wysocka \& Świerczewska 2010). One exception is the white color of quartz sandstones but they are characterized by a very thick bedding and normal grading (Fig. 4F).

Flaser and wavy beddings (Fig. 8A) are commonly present in the lacustrine deposits, commonly they co-ocurr with small-scale ripples, dwelling traces (Fig. 8B), coalified wood fragments and rich leaf inprints (Fig. 8D). Occasionally, the siderite concretions occur in mudstones and siltstones (Fig. 8C). Moreover, the crude flat bedding occurs in the Gh lithofacies with granule-sized grains. This displays the beginning of sedimentary rhythmicity. The sedimentary log consists of two parts: the lower part is interpreted as alluvial, while the upper one is of lacustrine origin (Fig. 9III). In the geochemical studies content of organic matter in mudstone and shale were measured and recorded the assemblages of alginite, sporinite and liptinite. They were interpreted as typical for lacustrine sediments (Petersen et al. 2005).

\section{DISCUSSION}

The coarse-grained facies predominates in sedimentary succession of the Hoanh Bo Basin. They are characterized by immature texture and poorly- to moderately sorting. The best examples of an alluvial fan facies were encountered in the Le Loi and Troi sections, close to the position of the Trung Luong Fault. Generally, the gravel facies are located around the margin of basin. However, the most coarse-grained facies (Gb, Gmm, Gic) predominate in the north and the northwest margins, where systems of alluvial fans and fluvial environment were developed. In contrast, the south and southeastern margins mainly consist of the fine-grained facies (Sm, Sng, Fms, Fm). Moreover, erosional contact between the Triassic and Neogene formations was observed. These facts suggest that the source area was in really close present proximity of the basin, probably in the present-day position. Especially, composition of grains of gravely lithofacies is similar to the Triassic rocks of the Hon Gai Formation as well as to the Jurassic rocks of the Ha Coi Formation.

According to Viet (2003), the shear surface of the Trung Luong Fault inclines to the south, in contrast, the one of the Chi Linh-Hon Gai Fault is inclined to the north. These evidences are easy to consider that the Hoanh Bo Basin was originated as a tectonic-controlled basin. The tectonic pattern represented activities such as brittle-ductile, brittle fractures, normal and left-lateral strike-slip accompanying with extension of faults, tectonic subsidence and uplift with a local scale (Tri \& Khuc 2009). This led to the phenomenon of abandoned channel was common in the studied area. The alluvial fans were developed along the Trung Luong Fault, in the north. The tectonic activity was continuing to configure the topographic surface and control the direction of water flows as well as the catchment area. Rivers debouched into the lake pool. Moreover, rivers had fed and supplied sedimentary materials to create the deltaic formation which could be seen in the Le Loi section. In the next stage, the ancient lake was gradually disappeared in order to transmute into the stage of main activity of the river and left the small ponds.

These typical ponds were fully filled with the strongly weathered pink-colored claystones (Fsm, Fm) which were situated in some small areas of Troi and Le Loi.

In general, the tectonic features and activity cause a slow subsidence inclining gradually from the north toward the northeast. This led the transmutation between the lake environment in the past up to the Ha Long Bay of the Tonkin Gulf.

\section{CONCLUSIONS}

The study of the sedimentary sequence of Paleogene/Neogene age from the Hoanh Bo Basin (Quang Ninh province, NE Vietnam) revealed the following results: 
1. The Hoanh Bo Basin is filled with continental sediments, mainly composed of polymictic conglomerates, sandstones, siltstones, claystones and shales.

2. The 17 lithofacies were recognized in the Hoanh Bo Basin infill as well as four facies association such as alluvial fan, fluvial, deltaic and lacustrine.

3. Marine fossils are absent in the investigated sedimentary sequence. Moreover, the presence of deltaic sediments is linked to lacustrine environment. Therefore, the geological pattern of the basin for the Paleogene/Neogene period should be interpreted as a small terrestrial basin flanked by hilly areas, with rivers flowing into the center of the basin occupied by a lake.

The anonymous journal referees are gratefully acknowledged for their revisions. They kindly offered critical comments and remarks, most of which were used by the authors to clarify and improve the content of the paper.

Field works were mainly supported by the Faculty of Geology, University of Warsaw (Poland) and partly by the project No. 105.01-2014.38 (Vietnam).

\section{REFERENCES}

Blair T.C. \& McPherson J.G., 1994. Alluvial fans and their natural distinction from rivers based on morphology, hydraulic processes, sedimentary processes, and facies assemblages. Journal of Sedimentary Research, A64, $450-489$.

Chinh V.V., 2002. Characteristics of neotectonic faults in the northeastern area of Vietnam. Institute of Geological Sciences, Vietnam Academy of Science and Technology (VAST), Hanoi [PhD dissertation, in Vietnamese].

Cuong N.Q. \& Zuchiewicz W., 2001. Morphotectonic properties of the Lo River Fault near Tam Dao in North Vietnam. Natural Hazards and Earth System Sciences, 1, $15-22$.

Cuong N.Q., 2007. Late Tertiary to Recent Tectonics of the Red River Fault Zone (Vietnamese part) Based on Studies of Sedimentary Rocks and Geomorphic Data. Institute of Geological Sciences, Polish Academy of Sciences, Kraków [PhD dissertation, unpublished].

Dovijkov A.E. (ed.), 1965. Geology of North Viet Nam. General Department of Geology and Minerals of Vietnam, Hanoi.

Eberth D.A. \& Miall A.D., 1991. Stratigraphy, sedimentology and evolution of a vertebrate-bearing, braided to anastomosed fluvial system, Cutler Formation (Permian, Pennsylvanian), north-central New Mexico. Sedimentary Geology, 72, 225-252.
Khuc V., 2001. New discover about stratigraphy of Jurassic sediments in Vietnam collecting in 6 years (1994-1999) and their signification. Journal of Geology, A/263, 6-22.

Khuc V. \& My B.P. (eds), 1988. Geology of Vietnam, Part I: Stratigraphy. General Department of Geology and Minerals of Vietnam, Hanoi.

Ky H.N. (ed.), 1999. Geology and mineral resources of the Hai Phong Map sheet, with the Geological Map of the Ha Long Sheet at 1:200,000 scale. General Department of Geology and Minerals of Vietnam, Hanoi.

Liem N.V., 1985. Late Paleozoic in Vietnam. Science and Technology Publishing House, Hanoi.

Luong N.C. (ed.), 1999. Geology and mineral resources of the $\mathrm{Ha}$ Long Map sheet, with the Geological Map of the $\mathrm{Ha}$ Long sheet, 1:200,000 scale. General Department of Geology and Minerals of Vietnam, Hanoi.

Massari F., 1983. Tabular cross-bedding in Messinian fluvial channel conglomerates, Southern Alps, Italy. [in:] Collinson J.D \& Lewin J. (eds), Modern and ancient fluvial systems, International Association of Sedimentologists, Special Publications, 6, 287-300.

McPherson J.G., Shanmugam G. \& Moiola R.J., 1987. Fan-deltas and braid deltas: Varieties of coarse-grained deltas. Geological Society of America Bulletin, 99, 331-340.

Miall A.D., 1977. A review of the braided river depositional environment. Earth Sciences Review, 13, 1-62.

Miall A.D., 1978. Lithofacies types and vertical profile models in braided river deposits: a summary. Canadian Society of Petroleum Geology Memoirs, 5, 597-604.

Miall A.D, 2006. The Geology of Fluvial Deposits. Springer-Verlag, Berlin.

Nemec W. \& Steel R.J., 1988. What is a fan delta and how do we recognize it? [in:] Nemec W. \& Steel R.J. (eds), Fan delta: Sedimentology and Tectonic Settings, Blackie and Son, London, 2-13.

Nhan T.D. \& Danh T., 1975. The new discovers about biostratigraphy of the Neogene sediments in the east of Bac Bo. [in]: Nhan T.D. \& Danh T. (eds), Stratigraphic Works, Science and Technology Publishing House, Hanoi, 244-283.

Patte E., 1927. Etudes géologiques dans I’Est du Tonkin. Bulletin du Service Géologiques de I'Indochinhe, Hanoi.

Petersen H.I., Tru V., Nielsen L.H., Duc A.N. \& Nytoft H.P., 2005. Source rock properties of lacustrine mudstones and coals (Oligocene, Dong Ho Formation), onshore of the Song Hong Basin, northern Vietnam. Journal of Petroleum Geology, 28(1), 19-38.

Pettijohn F.J., Potter P.E. \& Siever R., 1987. Sand and sandstones. $2^{\text {nd }}$ ed., Springer-Verlag, New York.

Postma G., 1990. Depositional architecture and facies of river and fan deltas: a synthesis. [in:] Albina C. \& David B.P. (eds), Coarse-grained deltas, The International Association of Sedimentologists, Blackwell Scientific Publications, Oxford, 13-28.

Quang P.V., 1969. The age of the coal-bearing deposits Hon Gai and the development of regional geology in Mesozoic. Journal of Geology, Hanoi, 13-39.

Quang P.V. (ed.), 1969. Report of Geological and Mineral resources for the coal basins in the northeast of Bac Bo (Quang Ninh) of Vietnam, scale 1:200,000. General Department of Geology and Mineral of Vietnam, Hanoi. 
Thanh T.D. \& Khuc V. (eds), 2009. Stratigraphic units of Vietnam. Vietnam National University Publishing House, Hanoi.

Tri T.V., 1977 (ed.). Geology of Viet Nam: The north part. Science and Technology Publishing House, Hanoi.

Tri T.V. \& Khuc V., 2009 (eds). Geology and Natural Resources of Vietnam. Natural Science and Technology $\mathrm{Pu}-$ blishing House, Hanoi.

Trung P.Q., Bat D., An N.Q., Khoi D.V. \& Hieu D.V., 1999. The new documentation of spore and pollen fossil in the Dong Ho formation. Journal of Petroleum Geology, Hanoi, 3, 2-8.

Tuc N.D., 2004. The modern activity of the Chi Linh-Dong Trieu fault zone. Journal of Sciences of the Earth, Hanoi, $4,26,587-597$.

Tucker M.E, 2001. Sedimentary Petrology. Blackwell Science, Oxford.

Tuyen T.T. (ed.) et al., 1995. Report of Geological and Mineral resources Map for group sheets Binh Lieu-Mong Cai, scale 1:50,000. Genaral Department of Geology and Minerals of Vietnam, Hanoi.
Udden J.A., 1914. Mechanical composition of clastic sediments. Geological Society of America Bulletin, 25, 655-744.

Uy N.D., 1995. Report of geological investigation in the Ha Long city. Vietnam Institute of Geosciences and Mineral Resources, Hanoi.

Viet L.T., 2003. Structural characteristics and Geodynamics of the Cenozoic basins in the North of Vietnam. Hanoi University of Mining and Geology, Hanoi [PhD dissertation, in Vietnamese, unpublished].

Wentworth C.K., 1992. A scale of grade and class terms for clastic sediments. Journal of Geology, 30, 5, 377-392.

Wysocka A. \& Świerczewska A., 2005. Tectonically-controlled sedimentation of Cenozoic deposits from selected basins along the Vietnamese segment of the Red River fault Zone. Acta Geologica Polonica, 55, 131-145.

Wysocka A. \& Świerczewska A., 2010. Lithofacies and depositional environments of Miocene deposits from tectonically-controlled basins (Red River Fault Zone, northern Vietnam). Journal of Asian Earth Sciences, 39, 109-124. 